\title{
音を利用した表面積の測定
}

\author{
鳥 越一 平*.石 井泰**
}

\section{Surface Area Measurement Utilizing Sound}

Ippei TORIGOE* and Yasushi IsHII**

\begin{abstract}
A principle is proposed for measuring the surface area of an object. The heat flow between an object and the surrounding medium is proportional to the surface area of the object. On this heat conduction law the surface area of an object can be measured. In this paper one of the possible embodiments of this principle - a method utilizing the acoustic impedance - is described. For sufficiently low frequencies, the acoustic impedance of a cavity of an adiabatic wall is capacitive. For real cavities, however, a real component arises from heat conduction at the wall. And the magnitude of this component is proportional to the area of the cavity wall. Therefore the surface area of the cavity, or of an object placed in a known container, can be known from the acoustic impedance measurement. In the first place, the acoustic impedance of a cavity is calculated assuming idealized conditions and the relationship is obtained between the cavity surface area and the acoustic impedance. In the second place, the influence to the acoustic impedance of the departures from the idealized conditions are investigated: the effects of the wall properties and the shape of the cavity. Finally, other influence quantities are enumerated and discussed summarily.
\end{abstract}

Key Words : surface area measurement, acoustic impedance, acoustic admittance, thermal boundary layer, Fourier's law of heat conduction.

\section{1.はじめに}

物体と周囲の気体との間に熱伝導によって流れる熱量が, 物体の表面積に比例することを利用した，表面積の測定原理 を提案する。本論文では, 原理の実現形態の一つ, 容器の音 響インピーダンスを利用する方法について述べる。

気体の満たされた容器に容積変動を加えると, 容器内の気 体の圧力と温度もまた変動する。もし容器内の気体の圧縮膨 張過程が断熱的であれば, 容器内の圧力変動(音圧) と容積変 動速度 (体積速度) との比 = 音響インピーダンスは容量性であ る.しかし, 現実の容器では, 容器の壁面で熱流が発生して エネルギー損失が生じ，音響インピーダンスには抵抗分が現 れる. そして, この抵抗分の大きさは容器内壁の表面積に比 例する。このことを利用すれば，音響インピーダンスから容 器の内表面積がわかる. あらかじめ内表面積のわかっている 容器に物体を入れて内表面積を測定すれば，物体の表面は音 響的には容器の内壁と同じだから，中に置かれた物体の表面 積も測定することができる.

\footnotetext{
†第36 回計測自動制御学会学術講演会で発表 $(1997 \cdot 7)$

* 熊本大学工学部 熊本市黒髪 2-39-1

** 計測科学研究所 川崎市高津区坂戸 100-1

* Faculty of Engineering, Kumamoto University, Kumamoto

** Measurement Science Laboratory, Kawasaki-shi, Kanagawa (Received March 14, 1997)

(Revised November 7, 1997)
}

物体の表面積は，物体が立方体や球などの場合には，簡単 な測定と公式によって計算できる。しかし，物体の形状が少 し複雑になると，三次元的な形状を正確に測定した上で数值 計算を行って求めるしかない，しかも，物体の三次元的な形 状の測定は，技術的にあるいはコスト的に，必ずしも容易で あるとは限らない。本論文で提案するのは，物理的に表面積 を測定する方法であり ; 表面積の全く新しい測定原理である. なお，ガスの吸着現象を利用して多孔質材料の比表面積が測 定されるが，本論文で想定している表面積測定とは測定の対 象を異にする方法である.

以下，まず理想的な条件のモデルによって基本的な原理を 説明する，次に，実際の容器の熱的特性や形状を考慮した場 合にどのような影響が出るかを検討する．

\section{2. 基本原理}

\section{1 記号}

本論文では以下の記号を用いる。

$$
\begin{aligned}
& c: \text { 音速 }\left(\mathrm{m} \mathrm{s}^{-1}\right) \\
& c_{p}: \text { 気体の等圧比熱 }\left(\mathrm{J} \mathrm{K}^{-1} \mathrm{~kg}^{-1}\right) \\
& c_{w}: \text { 壁の比熱 }\left(\mathrm{J} \mathrm{K}^{-1} \mathrm{~kg}^{-1}\right) \\
& d: \text { 平面壁間の距離または平板の厚み }(\mathrm{m}) \\
& e: \text { 気体の単位質量当たりの内部エネルギー }\left(\mathrm{J} \mathrm{kg}^{-1}\right) \\
& f: \text { 変動周波数 }\left(\mathrm{s}^{-1}\right) \\
& h: \text { 気体の単位質量当たりのエンタルピー }\left(\mathrm{J} \mathrm{kg}^{-1}\right) \\
& L: \text { 容器の代表寸法 }(\mathrm{m})
\end{aligned}
$$


$m:$ 気体の分子量

$P:$ 気体の圧力 $(\mathrm{Pa}), P=P_{0}+p$

$p:$ 気体の圧力の変動分 $(\mathrm{Pa})$

$q$ : 熱流 $\left(\mathrm{J} \mathrm{s}^{-1} \mathrm{~m}^{-2}\right)$

$R$ : 比気体定数 $\left(\mathrm{J} \mathrm{K}^{-1} \mathrm{~kg}^{-1}\right)$, 理想気体では $R=c_{p}-c_{v}$

$S_{r}:$ 容器の内表面積 $\left(\mathrm{m}^{2}\right)$

$S_{o}:$ 物体の表面積 $\left(\mathrm{m}^{2}\right)$

$S_{w}$ : 壁面の表面積 $\left(\mathrm{m}^{2}\right)$, 容器に物体が入っている場 合 $S_{w}=S_{r}+S_{o}$, 入っていない場合 $S_{w}=S_{r}$

$T:$ 温度 $(\mathrm{K}), T=T_{0}+\theta$

$U:$ 体積速度 $=$ 容器容積の時間変化 $\left(\mathrm{m}^{3} \mathrm{~s}^{-1}\right)$

$\boldsymbol{u}:$ 流速ベクトル $\left(\mathrm{m} \mathrm{s}^{-1}\right)$

$u_{n}:$ 流速の法線方向成分 $\left(\mathrm{m} \mathrm{s}^{-1}\right)$

$V_{0}:$ 容器の容積 $\left(\mathrm{m}^{3}\right)$

$\beta$ : 壁の温度変動の影響を表す無次元数,

$$
\beta=\left(\rho_{w} c_{w} \kappa_{w} / \rho_{a} c_{p} \kappa_{a}\right)^{1 / 2}
$$

$\gamma$ : 比熱比, $\gamma=c_{p} / c_{v}$, 常温常圧の空気では約 1.40

$\delta:$ 温度境界層の厚さ $(\mathrm{m}), \delta_{a}=\left(2 \kappa_{a} /\left(\rho_{a} \omega c_{p}\right)\right)^{1 / 2}$, $\delta_{w}=\left(2 \kappa_{w} /\left(\rho_{w} \omega c_{w}\right)\right)^{1 / 2}$

$\varepsilon$ : 音響インピーダンスに対する熱伝導の影響を表

寸無次元数, $\varepsilon=(\gamma-1) S_{w} \delta_{a} /\left(2 V_{0}\right)$,

$\varepsilon_{o}=(\gamma-1) S_{o} \delta_{a} /\left(2 V_{0}\right), \quad \varepsilon_{r}=(\gamma-1) S_{r} \delta_{a} /\left(2 V_{0}\right)$

$\kappa$ : 熱伝導率 $\left(\mathrm{J} \mathrm{s}^{-1} \mathrm{~m}^{-1} \mathrm{~K}^{-1}\right)$

$\lambda$ : 熱伝導方程式の固有値, $\lambda=(1-j) / \delta$,

$\lambda_{a}=(1-j) / \delta_{a}, \lambda_{w}=(1-j) / \delta_{w}$

$\rho:$ 密度 $\left(\mathrm{kg} \mathrm{m}^{-3}\right)$

$\rho_{0}:$ 気体の密度の時間平均值 $\left(\mathrm{kg} \mathrm{m}^{-3}\right)$

$\theta:$ 温度の変動分 $(\mathrm{K})$

$\omega:$ 変動の角周波数 $\left(\mathrm{s}^{-1}\right), \omega=2 \pi f$

添字

$$
\begin{aligned}
& o: \text { 時間平均量を表す } \\
& a: \text { 気体に関する量であることを表す } \\
& o: \text { 物体の寄与分を表す } \\
& r: \text { 容器の寄与分を表す } \\
& w: \text { 壁面に関する量であることを表す }
\end{aligned}
$$

\section{2 平面壁近傍の温度分布}

音響素子としての容器は，その寸法に比べて波長が十分に 大きい低周波領域では,気体の圧縮性に起因するコンプライア ンスと,容器壁面での熱伝導に起因するコンダクタンスとで表 現され，内部損失や粘性による抵抗分は無視できる大きさであ る ${ }^{1}$. 容器の熱伝導率と熱容量が無限に大きく, 壁面の温度が 一定であると仮定して，容器の音響インピーダンスを計算す る.このために, まず, 温度が一定 $\left(T_{0}\right)$ で無限に広い平面壁 $(x$ $=0)$ の上方 $(x>0)$ に非粘性の理想気体があって, 気体の圧力 $(P)$ が空間的に一様に時間変化する状況を考える.気体のエネ ルギー保存則は, $\rho_{a}$ を気体の密度, $e$ を単位質量当たりの内部 エネルギー, $\boldsymbol{u}$ を流速ベクトル,$q$ を熱流ベクトルとして

$$
\rho_{a} \frac{\mathrm{D} e}{\mathrm{D} t}=-P \operatorname{div} \boldsymbol{u}-\operatorname{div} \boldsymbol{q}
$$

と書かれる.圧力が独立変数となるようにエンタルピーへのル ジャンドル変換を行なえば, 単位質量当たりのエンタルピーを hとして

$$
\rho_{a} \frac{\mathrm{D} h}{\mathrm{D} t}=\frac{\mathrm{D} p}{\mathrm{D} t}-\operatorname{div} \boldsymbol{q}
$$

を得る。いま, 圧力変動は, 角周波数が $\omega=2 \pi f$ の正弦波で, また振幅が微小であるとする.理想気体におけるエンタルピー と温度の間の関係 $\left(\mathrm{d} h=c_{p} \mathrm{~d} T_{a}=c_{p} \theta_{a}\right)$ およびフーリエの熱伝導 の法則 $\left(q=-\kappa_{a} \operatorname{grad} \theta_{a}\right)$ を用い, また二次以上の微小項を無視 すると,(2)式は

$$
j \rho_{0} \omega c_{p} \theta_{a}=j \omega p+\kappa_{a} \operatorname{div} \operatorname{grad} \theta_{a}
$$

となる、ただし， $c_{p}$ は気体の等圧比熱， $\kappa_{a}$ は熱伝導率である. 今考えている状況では, 温度変動 $\theta_{a}$ の勾配は, 平面壁に垂直 な方向のみに生じるから,(3)式は

$$
j \rho_{0} \omega c_{p} \theta_{a}=j \omega p+\kappa_{a} \frac{\partial^{2} \theta_{a}}{\partial x^{2}}
$$

と書き表される。境界条件

$$
\begin{array}{cl}
x \rightarrow \infty & : \quad \theta_{a}(x, t) \rightarrow \theta_{a}(t) \\
x=0 & : \quad \theta_{a}(x, t)=0
\end{array}
$$

を考慮すれば,(4)式の解は

$$
\theta_{a}(x, t)=\frac{p}{\rho_{0} c_{p}}\left\{1-e^{-(1+j) x / \delta_{a}}\right\}
$$

と求まる。ここで $\delta_{a}$ は

$$
\delta_{a}=\sqrt{\frac{2 \kappa_{a}}{\rho_{0} \omega c_{p}}}
$$

であり,温度境界層の厚さを表している.(5)式の温度变動振幅 の概略を図にしたのがFig.1である.横軸の距離は, 温度境界 層の厚さ $\delta_{a}$ によって無次元化されている. Fig.1 からも見て取

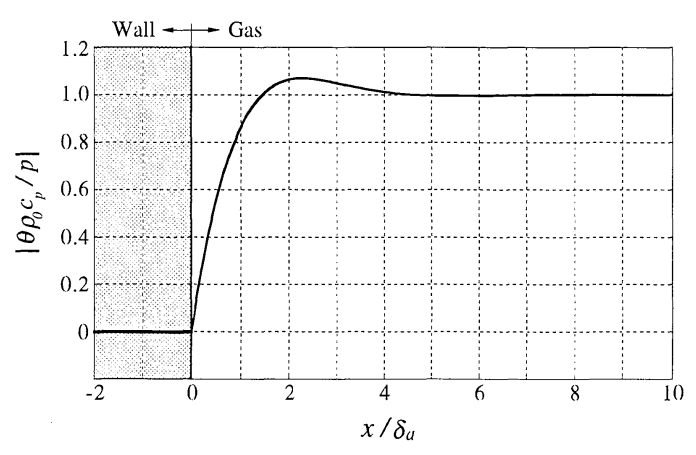

Fig.1 Ditribution of temperature variation amplitude above the wall.

れるように, 温度変動の振幅は, 壁近傍で等温壁の影響を受け るが, 境界層厚さの数倍程度離れるとほぼ一定の值 $\left|p / \rho_{0} c_{p}\right|$ となる。Fig. 2 は, $20^{\circ} \mathrm{C}, 1$ 気圧の空気の場合の境界層厚さ $\delta_{a}$ 
を，周波数に対してプロットしたグラフである.

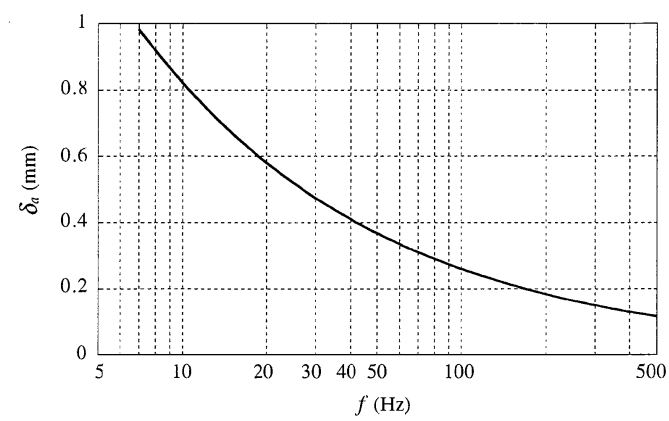

Fig.2 Boundary layer thickness as a function of frequency (For air of 20 ${ }^{\circ} \mathrm{C}, 1 \mathrm{~atm} . \rho_{a}=1.205 \mathrm{~kg} \mathrm{~m}^{-3}, \kappa_{a}=0.02572 \mathrm{~J} \mathrm{~s}^{-1} \mathrm{~m}^{-1} \mathrm{~K}^{-1}, c_{p}=1006 \mathrm{~J}$ $\left.\mathrm{K}^{-1} \mathrm{~kg}^{-1}\right)$.

\section{3 壁面温度一定の容器の音響インピーダンス}

次に, 非粘性の理想気体が充満した容積 $V_{0}$, 内表面積 $S_{w}$, 壁面温度 $T_{0}$ の容器を考え, その音響インピーダンスを計算す る.この容器に体積速度 $U$, 角周波数 $\omega$ の正弦的な容積変動を 加えるものとする.気体の状態変数の時間変化は, 状態方程式 を時間微分し，二次以上の微小項を無視して

$$
-\frac{j \omega \rho_{a}}{\rho_{0}}=-\frac{j \omega p}{P_{0}}+\frac{j \omega \theta_{a}}{T_{0}}
$$

で記述される。この式の両辺を容器全体にわたって体積積分す る. 左辺の積分は, 連続の式(質量保存則)

$$
-\frac{j \omega \rho_{a}}{\rho_{0}}=\operatorname{div} \boldsymbol{u}
$$

を使って

$$
\iiint_{V_{0}} \operatorname{div} \boldsymbol{u} \mathrm{d} v=\iint_{S_{w}} u_{n} \mathrm{~d} s=-U
$$

となる. 次に右辺の積分を考える.いま, 容器の代表長さ $L$ に 比較して容積変動の波長が十分に大きい，すなわち

$$
c / f>L
$$

であるなら, 圧力変動 $p$ は容器内の到るところで一様とみなす ことができる.また, 容器の代表長さ $L$ が温度境界層厚さ $\delta_{a}$ に 比べて十分に大きい，すなわち

$$
L \gg \delta_{a}
$$

が成り立つならば, 壁近傍の局所的な温度分布は, 先に求めた 平面壁近傍の温度分布に等しいと考えてよい. 容器の角や隅の 影響は, 高々 $\delta_{a}$ のオーダーの距離までしか及ばないから, 容 器全体の積分を考える場合には無視できる.結局, (7)式右辺の 積分は, 温度変動 $\theta_{a} に(5)$ 式の值を代入して

$$
-\frac{j \omega V_{0}}{\gamma P_{0}}\left\{1+(\gamma-1)(1-j) \frac{S_{w} \delta_{a}}{2 V_{0}}\right\} p
$$

と計算される.(9)(12)式から, 容器の音響インピーダンスが

$$
\begin{aligned}
\frac{p}{U}= & \frac{\gamma P_{0}}{j \omega V_{0}}\{1+(1-j) \varepsilon\}^{-1} \\
& \text { where } \quad \varepsilon=(\gamma-1) \frac{S_{w} \delta_{a}}{2 V_{0}}
\end{aligned}
$$

と求まる，あるいは音響アドミッタンスの形に書けば

$$
\frac{\omega V_{0}}{\gamma P_{0}} \varepsilon+j \frac{\omega V_{0}}{\gamma P_{0}}(1+\varepsilon)
$$

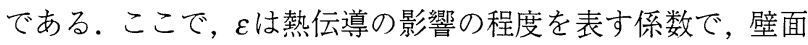
近傍にできる温度境界層の体積と容器全体の容積との比に比例 する.عは通常 1 に比べて十分小さいと考えてよいので,(13)式 の音響インピーダンスは近似的に

$$
\frac{\gamma P_{0}}{\omega V_{0}} \varepsilon-j \frac{\gamma P_{0}}{\omega V_{0}}(1-\varepsilon)
$$

となる. $\varepsilon \rightarrow 0$ の極限では, (13)式は断熱容器のインピーダン スに帰着する.(13)〜(15)式に見るように, 熱伝導のために, 音 響インピーダンスあるいは音響アドミッタンスには表面積に比 例した実数部が現れる(虚数部もまた影響を受け，見かけの容 積が増大寸る).(13)式あるいは(14)式に基づいて，音響イン ピーダンスの測定から容器の内表面積 $S_{w}$ を知ることができる.

\section{3 壁の温度変動の影響}

前章では, 容器壁の熱伝導率と熱容量が無限大で, 壁面温度 は一定温度であると仮定した. 実際の容器では, 壁の熱伝導率 と熱容量は有限だから,気体の温度変動に影響されて壁面温度 もまた変動する(Fig.3)．壁面の温度変動がどの程度の大きさ で, 表面積測定にどの程度影響を及ぼすかを見積もる。

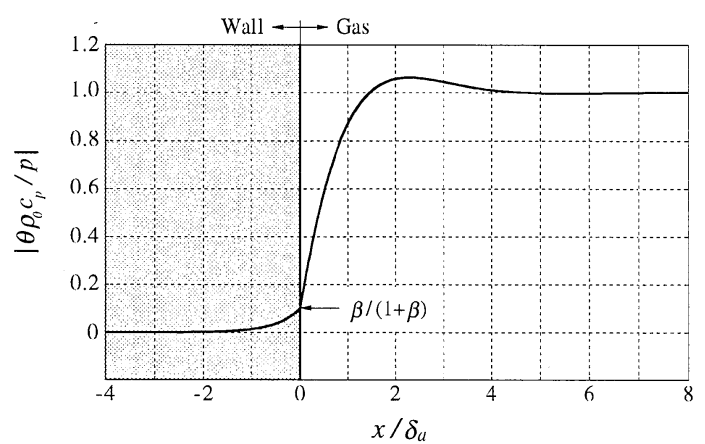

Fig.3 Distribution of the temperature variation amplitude of the wall and the gas $\left(\beta=0.1, \delta_{w}=\delta_{a} / 2\right)$.

壁が熱伝導率 $\kappa_{w}$, 比熱 $c_{w}$ の材料でできており，他の条件は 2. 2 節と同じである状況を考える. 壁は $x<0$ の領域に無限 に続いているものとする。この仮定は, 壁の厚さが壁内部の温 度境界層厚さ $\delta_{w}$ に比べて十分大きければ, 妥当な仮定である. 熱伝導の式は,

$$
\begin{aligned}
& x \geq 0: j \rho_{0} \omega c_{p} \theta_{a}=j \omega p+\kappa_{a} \frac{\partial^{2} \theta_{a}}{\partial x^{2}} \\
& x \leq 0: j \rho_{w} \omega c_{w} \theta_{w}=\kappa_{w} \frac{\partial^{2} \theta_{w}}{\partial x^{2}}
\end{aligned}
$$


と書かれる.(16)式を，壁面で温度と熱流が連続であるという 境界条件

$$
\begin{aligned}
& x \rightarrow \infty: \theta_{a}(x, t) \rightarrow \theta_{a}(t) \\
& x=0: \quad \theta_{a}(x, t)=\theta_{w}(x, t), \quad \kappa_{a} \frac{\partial \theta_{a}}{\partial x}=\kappa_{w} \frac{\partial \theta_{w}}{\partial x} \\
& x \rightarrow-\infty: \theta_{w}(x, t)=0
\end{aligned}
$$

のもとで解けば,

$$
\theta_{a}(x, t)=\frac{p}{p_{0} c_{p}}\left\{1-\frac{1}{1+\beta} e^{-(1+j) x / \delta_{a}}\right\}
$$

が得られる.ここで， $\beta$ は

$$
\beta=\sqrt{\frac{\rho_{a} c_{p} \kappa_{a}}{\rho_{w} c_{w} \kappa_{w}}}\left(=\frac{\rho_{a} c_{p} \delta_{a}}{\rho_{w} c_{w} \delta_{w}}\right)
$$

で定義され, 容器壁の温度変動の影響の程度を表すパラメー ターとなる。なお，括弧内に示したように， $\beta$ は, 気体の温度 境界層の熱容量と壁の温度境界層の熱容量の比に等しい.壁面 の温度变動の振幅は, 遠方の気体の振幅 $p / \rho_{0} c_{p}$ の $\beta /(1+\beta)$ 倍 である (Fig.3).(17)式の温度分布を用いて, 容器の音響イン ピーダンスを計算すると,

$$
\frac{p}{U}=\frac{\gamma P_{0}}{j \omega V_{0}}\left\{1+(1-j) \varepsilon \frac{1}{1+\beta}\right\}^{-1}
$$

が得られる. 等温壁の場合の(13)式と比較すると, 壁の温度変

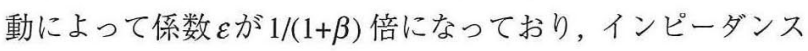
から表面積を測定した場合, 表面積は $1 /(1+\beta)$ 倍に見積もられ

\begin{tabular}{|c|c|c|c|c|c|}
\hline & $\mathrm{Cu}$ & $\mathrm{Al}$ & $\begin{array}{l}\text { Wood } \\
\text { (pine) }\end{array}$ & $\begin{array}{l}\text { Acrylic } \\
\text { resin }\end{array}$ & Water \\
\hline $\begin{array}{c}\rho_{w} \\
\left(\mathrm{~kg} \mathrm{~m}^{-3}\right)\end{array}$ & 8930 & 2690 & 520 & 1190 & 998.2 \\
\hline 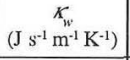 & 401 & 237 & 0.14 & 0.17 & 0.60 \\
\hline $\begin{array}{c}c_{w} \\
\left(\mathrm{~J} \mathrm{~K}^{-1} \mathrm{~kg}^{-1}\right)\end{array}$ & 384 & 898 & 1250 & 1464 & 4182 \\
\hline$\beta$ & 0.000015 & 0.00023 & 0.0185 & 0.0103 & 0.0035 \\
\hline
\end{tabular}
る.いくつかの材料について(気体側は $20^{\circ} \mathrm{C}, 1$ 気圧の空気)， $\beta$ の值を Table 1 に示す. ほとんどの金属や多くの固体・液体 において, $\beta$ の值は十分に小さく, 表面積測定への壁面温度変 動の影響は無視しうる.しかし，ある種の木材や樹脂など熱伝 導の悪い材料で, 影響が $2 \%$ 程度に達するものがある.

Table 1 Thermal properties of various materials. The $\beta$ 's are the value for air of $20^{\circ} \mathrm{C}$ and $1 \mathrm{~atm}$.

\section{4 形状の影響}

ここまでの議論では, (11)式が成り立つ一温度境界層の厚さ

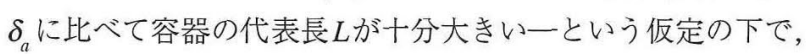
平面壁近傍の温度分布を用いてインピーダンスを計算した。し かし厳密に言えば, 壁面に曲率があると, 温度分布は平面壁の 場合とは異なる。また，壁は $x<0$ の領域に無限に広がってい
ると見なして計算をしたが, 実際の壁の厚さは有限である.こ れら実際の壁面における「形状の影響」について検討する。た だし,任意の形状について影響を理論的に求めることは不可能 である.ここでは,いくつかの単純で代表的な形状について検 討する.一般の形状は,これらの形状を組み合わせておおまか に近似できる.一般の形状における影響の目安も, 以下の検討 結果を組み合わせて得ることができる.

(1) 円筒形空間 半径 $a$ の円筒空間について, 上下の端の 影響の及ばない場所での気体温度分布を考える. 円筒の中心軸 を $z$ 軸, 動径を $r$ とする円筒座標系をとると, 熱伝導の方程式 はベッセル方程式となる.これを, 壁面での温度と熱流が連続 であるという条件の下に解き, 円筒の上下端面からの寄与を無 視して音響インピーダンスを計算すると,

$$
\frac{\gamma P_{0}}{j \omega V_{0}}\left\{1+(1-j) \varepsilon \frac{j \mathrm{~J}_{1}\left(\lambda_{a} a\right)}{\mathrm{J}_{0}\left(\lambda_{a} a\right)} \cdot \frac{\frac{\mathrm{H}_{1}^{(2)}\left(\lambda_{w} a\right)}{j \mathrm{H}_{0}^{(2)}\left(\lambda_{w} a\right)}}{\frac{\mathrm{H}_{1}^{(2)}\left(\lambda_{w} a\right)}{j \mathrm{H}_{0}^{(2)}\left(\lambda_{w} a\right)}+\beta \frac{j \mathrm{~J}_{1}\left(\lambda_{a} a\right)}{\mathrm{J}_{0}\left(\lambda_{a} a\right)}}\right\}^{-1}
$$$$
\text { where } \lambda_{a}=(1-j) / \delta_{a}, \lambda_{w}=(1-j) / \delta_{w}
$$

となる．ここでJは第一種ベッセル関数, $\mathrm{H}^{(2)}$ は第二種ハンケ ル関数である.壁面の温度变動と壁面が円筒面であることの影 響が, $\varepsilon に$ 係数が掛かる形で現れ, 表面積測定にも影響が及ぶ ことが分かる. $\beta$ が十分に小さく壁面の温度変動が無視しうる 場合は，(20)式は

$$
\frac{\gamma P_{0}}{j \omega V_{0}}\left\{1+(1-j) \varepsilon \frac{j \mathrm{~J}_{1}\left(\lambda_{a} a\right)}{\mathrm{J}_{0}\left(\lambda_{a} a\right)}\right\}^{-1}
$$

となる. $\lambda_{a} a$ の絶対値が大きくなると, すなわち円筒半径 $a$ が 温度境界層厚さ $\delta_{a}$ に比較して大きくなると,(21)式は(13)式に漸 近し, 円筒側面を平面壁と見なして計算した結果と等しくな る.半径 $a$ か十分には大きくない場合,(21)式の実数部は(13)式 の值より小さくなり, 表面積も小さく見積もられることにな る.具体的に数值例を挙げると, 円筒面であることの影響がー $5 \%$ となるのは, $a$ が $\delta_{a}$ の約 10 倍のとき, $-2 \%$ になるのは 約 25 倍のときである.一方, $\lambda_{a} a$ の絶対值が小さくなると, 気 体の状態変化は等温過程に近づき, 空間のインピーダンスも等 温過程の場合のそれに近づく. $a$ が $\delta_{a}$ の約 0.3 倍以下ならば, 円筒内の気体の温度変動振幅は断熱過程の場合の振幅 $p / \rho_{0} c_{p}$ の $5 \%$ 以下である.

(2)球形空間 半径 $a$ の球形空間について, 壁面の温度変 動の影響を無視して音響インピーダンスを計算すると

$$
\frac{\gamma P_{0}}{j \omega V_{0}}\left\{1+(1-j) \varepsilon\left(\frac{j}{\lambda_{u} a}-j \cot \lambda_{a} a\right)\right\}^{-1}
$$

となる.やはり, $\left|\lambda_{a} a\right| \rightarrow \infty$ の極限では壁面を平面と見なし た場合のインピーダンス(13)に漸近し, 一方, $\left|\lambda_{a} a\right| \rightarrow 0 の$ 極限では等温過程のインピーダンスに漸近する.球面性の影響 
がー $5 \%$ となるのは $a$ が $\delta_{a}$ の 20 倍のとき, $-2 \%$ にるのは 50 倍のとき, また, 温度変動振幅が断熱過程の振幅の $5 \%$ 以 下となるのは, $a$ が $\delta_{a}$ の約 0.4 倍のときである. 壁面の温度変 動を考慮した場合は, (22)式中の $\varepsilon$ の係数が次の值となる.

$$
\varepsilon\left(\frac{j}{\lambda_{a} a}-j \cot \lambda_{a} a\right) \times \frac{\left(1-\frac{j}{\lambda_{w} a}\right)}{\left(1-\frac{j}{\lambda_{w} a}\right)+\beta\left(\frac{j}{\lambda_{a} a}-j \cot \lambda_{a} a\right)}
$$

（３）平面壁間の細隙 二つの平行な平面壁に挟まれた間隔 $d$ の細隙を考える．細隙の容積を $V_{0}$, 内表面積を $S_{w}$ とし, 端 と壁面温度変動の影響を無視すると，音響インピーダンスは

$$
\frac{\gamma P_{0}}{j \omega V_{0}}\left\{1+(1-j) \varepsilon j \tan \left(\lambda_{a} d / 2\right)\right\}^{-1}
$$

である. 細隙の間隔(境界層厚さで正規化した)に対して, 細隙 の内表面積がどう測定されるかをグラフにしたのがFig.4であ る. dが小さいと, 細隙内の温度変動が小さくなり, 内表面積 が実際よりも小さく見積もられるという大局的傾向は円筒形空 間や球形空間と同じであるが, 境界層厚さの 3 倍付近に, 逆に 表面積が大きめに見積もられる領域が存在する.

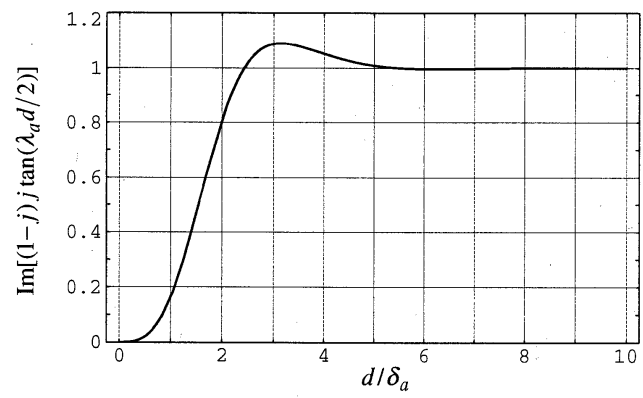

Fig.4 Gap distance influence to the estimate of the surface area.

空間の音響インピーダンスを求めることは，空間内の気体 の見かけの体積弾性率を計算することと等価である.上記の三 形状の空間について,体積弾性率を計算した報告がいくつかあ る。上の (1)〜(3)で壁面温度変動を無視した場合の結果は，既 報の計算結果と一致している2).なお，上記(1)〜(3)の結果は， 容器自体が当該形状である場合だけでなく,物体表面の空洞や 物体と容器壁との間の隙間として,これらの形状要素が含まれ る場合にも適用できる。

(4) 平板状物体 片面の面積が $S_{o} / 2$ で厚さ $d$ の平板が容 器内に在る場合を考える.この場合の容器の音響インピーダン スは, 平板の側面面積と壁面温度変動が無視しうるならば

$$
\frac{\gamma P_{0}}{j \omega V_{0}}\left\{1+(1-j)\left(\varepsilon_{r}+\varepsilon_{o}\right)\right\}^{-1}
$$

である.ただし $\varepsilon_{r}$ おび $\varepsilon_{o}$ は，それぞれ，容器壁面がインピー ダンスに与える影響と物体表面がインピーダンスに与える影響 を表す係数である.この平板の厚さ $d$ 薄くなり, 平板内部で の温度境界層厚さ $\delta_{w}$ と同程度以下になると, 平板の厚みが十
分に大きいとは言えなくなる.この場合, 平板全体の温度が気 体の温度変動に影響される.平板内の温度変動を考慮に入れて インピーダンスを計算すると，

$$
\frac{\gamma P_{0}}{j \omega V_{0}}\left\{1+(1-j)\left(\varepsilon_{r}+\varepsilon_{o} \frac{j \tan \left(\lambda_{w} d / 2\right)}{j \tan \left(\lambda_{w} d / 2\right)+\beta}\right)\right\}^{-1}
$$

となる.|$\lambda_{w} d \mid \rightarrow \infty$ のき，すなわち $d$ が $\delta_{w}$ に比べて大き いときは, $\tan \left(\lambda_{w} d / 2\right) \rightarrow 1 / j$ だから,(26)式中の $\varepsilon_{0}$ の係数は $1 /$ $(1+\beta)$ に近づき， 3 章の結果と整合する. $d$ が小さくなったと きどの程度の影響がでるかを,一例としてアルミニウム板につ

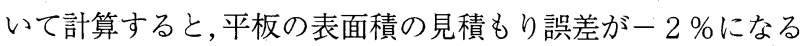
のは, 厚さ $d$ が $\delta_{w}$ の 0.024 倍のときである. 家庭用アルミフォ イルの厚さは約 $15 \mu \mathrm{m}$ であり，仮に周波数 $40 \mathrm{~Hz}$ で測定したと すると, 表面積の見積もり誤差は一 $2.9 \%$ 程度と計算される.

( 5 ) 円柱状物体 半径 $a$ で長い円柱状の物体が容器内に在 る場合を考える。この容器の音響インピーダンスは, 容器の寸 法が大きくて円柱周辺に十分な空間があるとし，また円柱の上 下面の効果と物体の温度変動を無視すれば

$$
\frac{\gamma P_{0}}{j \omega V_{0}}\left\{1+(1-j)\left(\varepsilon_{r}+\varepsilon_{o} \frac{\mathrm{H}_{1}^{(2)}\left(\lambda_{a} a\right)}{j \mathrm{H}_{0}^{(2)}\left(\lambda_{a} a\right)}\right)\right\}^{-1}
$$

である. 円柱の半径 $a$ が温度境界層厚さ $\delta_{a}$ より十分に大きい 場合には, (27)式は(13)式に漸近する. 円柱半径 $a$ が小さくなる と, 物体の表面が円筒面である影響が現れ, 表面積は実際より 大きめに見積もられる．表面積 $S_{0}$ が $+5 \%$ の誤差で見積もら れるのは， $a$ が $\delta_{a}$ の約 10 倍のときである。.さらに $a$ が小さく なって $\delta_{w}$ と同程度以下になると, 円柱内部の温度变動の影響 が現れる，円柱内部の温度変動を考慮した場合には,(27)式中 の $\varepsilon_{0}$ の係数が次式となる.

$$
\varepsilon_{o} \frac{\mathrm{H}_{1}^{(2)}\left(\lambda_{a} a\right)}{j \mathrm{H}_{0}^{(2)}\left(\lambda_{a} a\right)} \times \frac{\frac{j \mathrm{~J}_{1}\left(\lambda_{w} a\right)}{\mathrm{J}_{0}\left(\lambda_{w} a\right)}}{\frac{j \mathrm{~J}_{1}\left(\lambda_{w} a\right)}{\mathrm{J}_{0}\left(\lambda_{w} a\right)}+\beta \frac{\mathrm{H}_{1}^{(2)}\left(\lambda_{a} a\right)}{j \mathrm{H}_{0}^{(2)}\left(\lambda_{a} a\right)}}
$$

（6 球状物体半径 $a$ の球状物体が容器内にある場合の音 響インピーダンスは, 物体の温度変動を無視すれば

$$
\frac{\gamma P_{0}}{j \omega V_{0}}\left\{1+(1-j)\left(\varepsilon_{r}+\varepsilon_{o}\left(1-\frac{j}{\lambda_{a} a}\right)\right)\right\}^{-1}
$$

である. 物体の表面積 $S_{o}=4 \pi a^{2}$ が+ $5 \%$ の誤差で見積もら れるのは, 半径 $a$ が境界層厚さ $\delta_{a}$ の 20 倍のときである. $a$ が 小さく球内部の温度変動の影響が無視しえない場合には, (29) 式中の $\varepsilon_{0}$ の係数が次式となる.

$$
\varepsilon_{o}\left(1-\frac{j}{\lambda_{a} a}\right) \times \frac{\left(\frac{j}{\lambda_{w} a}-j \cot \lambda_{w} a\right)}{\left(\frac{j}{\lambda_{w} a}-j \cot \lambda_{w} a\right)+\beta\left(1-\frac{j}{\lambda_{a} a}\right)}
$$




\section{5. 他の影響量}

表面積測定への影響量として; 壁の熱的特性と形状につい て検討した。この他の影響量として以下のものを考慮する必要 がある。

（1）圧縮性の影響容器が集中定数系と見なせるのは,式 (10)が成り立つときである.容器の代表長さが波長に比較して 十分に小さいという仮定が成り立たない場合には,もはや圧力 が容器内で一様とは見なせなくなる。このことによる影響一気 体の圧縮性あるいは音速の有限性の影響といってもよい一は, $(\omega L / c)^{2} / 3$ のオーダーである ${ }^{3)}$. 4 章の検討から分かるよう に, 一般に, 小さい容器や物体ほど表面積測定の誤差が大きく なる.小さい物体の表面積を正確に測定するには, 温度境界層 厚さ $\delta_{a}$ を小さする必要がある。そのためには高い周波数で の音響インピーダンスを用いることになり，これにあわせて測 定用容器も小さくする必要がある。しかし, 温度境界層厚さが 周波数の $1 / 2$ 乗に反比例するのに対して, 圧縮性の影響は周波 数の 2 乗のオーダーであるから, 単純に単一周波数における音 響インピーダンスから表面積を求めるとすれば, 測定できる物 体の大きさに下限が存在することがわかる。

（2）体積（13）または(15)式から分かるように, 音響抵抗 は内表面積だけでなく容積にも依存している.このことは, 物 体を容器に入れて測定する場合に, 物体の表面積が同じでも, 物体の体䅡が異なれば音響抵抗は異なることを意味する。従っ て, 音響抵抗を測定して表面積を知る場合には, 物体の体積を 何らかの手段で測定する必要がある.音響インピーダンスの実 数部だけでなく虚数部の情報も利用すれば,物体体積を知るこ とができる3415)。なお，音響コンダクタンスを測定する方法を とる場合は, 容器容積の影響を受けない.

(3)容器と物体のスティフネス 容器内の圧力が変動した とき容器壁面または物体表面が変位すると,すなわち容器ある いは物体のスティフネスが有限であると, 音響インピーダンス は, 容積が増大したのと等価な影響を受ける。この影響は表面 積測定の誤差要因となる. 容器と物体が十分に「硬い」ことが 必要である。

(4)平均圧カ・温度・比熱比音響インピーダンスは容器 内の平均圧力 $P_{0}$ によって変化する. また, 温度が変化すると, 気体の境界層厚さが影響を受ける.従って, 容器内の平均圧力 (通常は大気圧に等しい) と温度をあわせて測定するか,これら の量の影響を受けない測定法を工夫しなくてはならない. 比熱 比 $\gamma$ の変化は, 平均圧力や温度の变化に対しては小さいが, 気 体の組成変化に対してはかなりの大きさとなる場合がある.空 気中で測定する場合には, 測定者の呼気による湿度変化に注意 する必要がある。

\section{6.まとめ}

物体表面積を音を使って測定する方法を提案し, 原理的な 検討をおこなった.その結果次のことが明らかになった。(1)容 器の音響抵抗または音響コンダクタンスが容器内表面積に比例
し, 音響インピーダンスの測定によって物体の表面積を知るこ とができる.(2)壁面の材質の影響は小さく,一部の材質のしか も高精度を要求する場合を除けば無視できる.(3)被測定物の形 状が表面積の見積もりに影響を与える。一般的に小さな物ほど 影響が大きく, 測定可能な物体の大きさに, 使用周波数と許容 誤差に応じた下限が存在する。

以上の他にも検討すべき原理上の問題がいくつかある．例 えば, 本論文では物体表面を平滑な面に限定しているが, 物体 表面が布や毛皮のような材料で被われている場合に,どのよう な量を測定することになるのかという問題である.このような 物体も，4章で検討した要素形状の組み合わせで近似的にモデ ル化しうるが,一般的にまた理論的に取り扱うことは困難で, それぞれの場合に応じて数值的方法などによって検討する必要 がある。

表面積の情報を担うのは，微小な音圧中のさらに微小な成 分である.上述の誤差要因の影響を免れて表面積を測定するこ とは, 従って簡単ではないが, 測定上の工夫を凝らせば可能で ある(). 実際の装置化の例と実験結果については別に報告する 予定である.

本研究は文部省科学研究費 (平成 8 年度 No.08650502)の援助 を受けた。

\section{参考文献}

1) Uno Ingard: On the Theory and Design of Acoustic Resonators, J. of the Acoustical Society of America, 25-6, $1037 / 1062$ (1953)

2) 早坂, 吉川：音響振動論, 707, 丸善 (1974)

3) 鳥越, 石井: 音響ブリッジ式容積計, 計測自動制御学会論文集, 30-11, 1303/1309 (1994)

4) 鳥越，石井：ボイルシャルルの法則による容積測定，日本音響 学会講演論文集, $253 / 254$ (1982)

5) 石井 泰：音響式容積計,計測と制御, 36-4, 288/291 (1997)

6) 鳥越一平：音響ブリッジを利用した表面積測定，第 35 回 SICE 学術講演会予稿集, 975/976(1996)

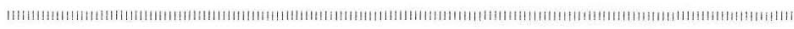

「著 者 紹 介」

鳥 越 一 平 (正会員)

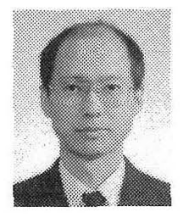

1979年, 東京大学大学院計数工学専攻課程修士課 程修了. 同年富士電機製造(株) 入社. 80 年東京大学 宇宙航空研究所助手, 90 年熊本大学総合情報処理セ ンター助教授、97年より同大学工学部助教授. 流体 計測, 音響応用計測の研究に従事 (工学博士).

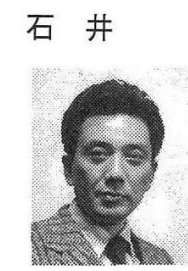

泰 (正会員)

1959年, 東京大学大学院応用物理学専攻博士課程 修了. 同年同大学航空研究所助手, 同助教授, 教授 を経て, 92年同大学先端科学技術研究センターを退 職, 同年計測科学研究所所長. 信号処理, 音響応用 計測の研究に従事(工学博士). 